\title{
Early Prevention of Maternal Sexual Abuse
}

\author{
Jelena Gerke ${ }^{1} \cdot$ Tatjana Dietz $^{2}$ (D)
}

Accepted: 17 May 2021 / Published online: 21 June 2021

(c) The Author(s) 2021

\begin{abstract}
Child sexual abuse has been discussed thoroughly; however, marginalized groups of victims such as victims of child sexual abuse in early childhood and victims of maternal sexual abuse have rarely been considered. This essay combines these two relevant perspectives in child protection and aims to pin out future directions in the field of child abuse and specifically maternal sexual abuse and its early prevention. In the course of the 7th Haruv International $\mathrm{PhD}$ Workshop on Child Maltreatment at the Hebrew University, Jerusalem, in 2019 the topics of maternal sexual abuse and early prevention of child maltreatment in Germany were discussed and intertwined. Problems concerning the specific research of maternal sexual abuse in early childhood and prevention were identified. Both, maternal sexual abuse as well as sexual abuse in early childhood, i.e. before the age of three, are underreported topics. Society still follows a "friendly mother illusion" while recent cases in German media as well as research findings indicate that the mother can be a perpetrator of child sexual abuse. Similarly, sexual abuse in early childhood, namely abuse before the age of three, is existent; although the recognition of it is difficult and young children are, in regards to their age and development especially vulnerable. They need protective adults in their environment, who are aware of sexual abuse in the first years of life. Raising awareness on marginalized or tabooed topics can be a form of prevention. An open dialog in research and practice about the so far marginalized topics of maternal sexual abuse and sexual abuse in early childhood is crucial.
\end{abstract}

Keywords Maternal sexual abuse $\cdot$ Prevention $\cdot$ Child sexual abuse $\cdot$ Early childhood

Jelena Gerke and Tatjana Dietz contributed equally to the paper

Tatjana Dietz

T.Dietz@em.uni-frankfurt.de

Jelena Gerke

jelena.gerke@uniklinik-ulm.de

1 Department of Child and Adolescent Psychiatry/Psychotherapy, University Hospital Ulm, Ulm, Germany

2 Faculty of Educational Sciences, Institute for Social Pedagogy and Further Education, GoetheUniversity Frankfurt, Frankurt, Germany 


\section{Introduction}

Child sexual abuse is a global phenomenon with prevalences ranging internationally between 13-20\% for female victims and 5-8\% for male victims (Barth et al., 2013; Pereda et al., 2009; Sethi et al., 2013; Stoltenborgh et al., 2011). The negative long-term influences on children's lives are clear in evidence (e.g., Brüning et al., 2019; Children's Commissioner for England, 2015; Clemens et al., 2018; Egle \& Hardt, 2012; Felitti et al., 1998; Hillberg et al., 2011; Kendall-Tackett et al., 2005; Witt et al., 2016; Zimmermann, 2010). Even though child sexual abuse occurs in different social environments, under individual circumstances and in different age groups, the focus in research, practice and society is mainly on the most frequent types of child sexual abuse, i.e. with male perpetrators and female victims. Research and an open dialog in practice and public on marginalized subtypes of child sexual abuse are rare. Sexual abuse in early childhood, i.e. before the age of three, as well as female-perpetrated child sexual abuse and specifically maternal child sexual abuse have been given little consideration. The starting point of the following essay on future directions in the field of child protection is to discuss these relevant blind spots and to present knowledge and ideas about the difficulties of recognizing these phenomena and possible ways of prevention.

This essay is part of a collection of papers on future directions in the field of child protection and a result from the 7th Haruv International PhD Workshop on Child Maltreatment at the Hebrew University, Jerusalem. The workshop offered young researchers through scholarships the possibility to discuss their research and develop ideas and implications for research and practice. Considering our research topics of maternal sexual abuse as well as the prevention of maltreatment up from the time of birth, the topic of maternal sexual abuse in infancy and early childhood arose. Yet, there are several difficulties as the topic is highly tabooed and hidden. Therefore, the first step to shed light in these areas of research and child protection is to collect existing knowledge and raise awareness. The aim of this essay is to pin out the role of the mother as a possible perpetrator of child sexual abuse with a special focus on early childhood. Therefore, children up to three years of age are in the focus and referred to when talking about early childhood, as children in this age group are mainly cared by their family environment. Discussing these topics, we will focus on the German child protection system.

\section{Female-Perpetrated Child Sexual Abuse}

Large international epidemiological studies have not considered the gender of the perpetrator (Barth et al., 2013; Pereda et al., 2009; Sethi et al., 2013; Stoltenborgh et al., 2011). However, there is female-perpetrated child sexual abuse in one to $6 \%$ of cases with female victims and $6 \%$ to $17 \%$ of cases with male victims (Bieneck et al., 2011; Deering \& Mellor, 2010; Finkelhor \& Russell, 1984; Finkelhor et al., 2014; Gerke et al., 2019a; Kocturk \& Yuksel, 2019). In a large data analysis of every substantiated child sexual abuse case reported to child protective services in the United States for 2010, slightly over $20 \%$ involved a female primary perpetrator and in cases with two perpetrators over $42 \%$ of the co-offenders were female (McLeod, 2015). In a meta-analysis, Colson et al. (2013) illustrate that women appear to commit sexual abuse in an opportunistic manner. They describe that female perpetrators are more likely to abuse their own children or other 
close relatives than extra-familial victims, so they seem to abuse victims who are accessible to them rather than through a specific choice of gender (Colson et al., 2013). Other studies find an effect of victim gender, such that female perpetrators rather abuse male victims while male perpetrators rather abuse female victims (Dube et al., 2005; Gerke et al., 2019a). Moreover, female perpetrators often seem to be victims of sexual abuse or other types of childhood maltreatment themselves (Colson et al., 2013).

Further uncertainties in research are the proportion of primary perpetration by females versus co-perpetration as well as the severity of female-perpetrated child sexual abuse. A criminological weighting of severity of sexual abuse is often given based on a classification of sexual abuse without ("hands-off", e.g. voyeurism, viewing pornographic material, digitally sending or requesting photos with sexual content) and with physical contact ("hands-on", e.g. touching genitals, penetration with own body parts or objects, requesting touch or stimulation). In counseling or therapy, as well as for long-term consequences, however, much greater importance must be attached to the subjective perception and processing of sexual abuse than to the objective classification into "moderate" and "severe" abuse (Fegert et al., 2013). Grayston and De Luca (1999) report in their literature review that most female perpetrators offend with a co-perpetrator and rather engage in abuse of "moderate" intensity. Contrary to that, another literature review concludes, that the majority of female perpetrators offend alone and that female perpetrators do engage in "severe" forms of sexual abuse such as penetration (Johansson-Love \& Fremouw, 2006).

\section{Maternal Sexual Abuse}

There is a "friendly mother illusion" in society suggesting that mothers do not engage in sexual abuse and would protect and care for their children. However, in some cases they are the perpetrator of sexual abuse. There is a need to discuss these cases in research, politics and practice. The mother (not including foster parent or other caretaker) was the primary perpetrator in $78 \%$ of female-perpetrated child sexual abuse cases while the father was the primary perpetrator in only $31 \%$ of male-perpetrated child sexual abuse (MCSA) cases (McLeod, 2015). Hunger (2019) describes in her analysis of criminal records and prosecution statistics in Germany, as well, that, within cases of child sexual abuse by relatives, mothers were named more often as a perpetrator compared to fathers. Other studies find lower numbers of maternal perpetrators within all perpetrators of child sexual abuse, i.e. $4.2 \%$ to $8.9 \%$ (Jimenez-Borja et al., 2020), or cannot name a specific prevalence due to small samples but state that a majority of victims abused by females name their mother as a perpetrator (Denov, 2003; Kendall-Tackett \& Simon, 1987). Prevalences are still unclear; however, it is evident that there is sexual perpetration by mothers and it might be underestimated.

Underreporting could be due to the special role of females and specifically mothers within society. Mothers have a caring and protecting role in society and are allowed a great range of physical contact with children. They are often responsible for hygiene and medical care; therefore, the boundary between non-abusive and abusive behavior is much more difficult to identify (Banning, 1989; Hetherton \& Beardsall, 1998; Oliver, 2007). Considering society's sexual scripts, females are expected to be less sexually interested and aggressive, while men are considered the aggressor and the leading part in sexual interactions (Sahl \& Keene, 2010; Wiederman, 2005). These gendered sexual scripts lead to a sexual double standard in the perception of sexual abuse, i.e. in vignette studies participants rated sexual 
abuse less negatively when the perpetrator was a female (Geddes et al., 2013; Maynard \& Wiederman, 1997; Rogers \& Davies, 2007; Wiederman, 2005). The same gendered sexual script and sexual double standard were described in studies with professional samples (for a review see Gerke et al., in review). Accordingly, victims describe experiences of disbelief and trivialization when disclosing female-perpetrated child sexual abuse (Deering \& Mellor, 2011; Denov, 2003; Harris \& Mayba, 2017). Male victims specifically describe being laughed at (Deering \& Mellor, 2011; Harris \& Mayba, 2017). Maternal sexual abuse is additionally sensitive as mothers are not only an important attachment figure to the child but also most often the child's contact person to the school, the medical system etc. (Peter, 2008).

Sexual abuse committed by mothers is a severe experience for a child as the person who is liable for care, safety and belonging, violates her responsibility and hurts the child in a physical as well as emotional way. When the mother is the perpetrator of abuse, there is rarely a non-abusing parent, while in case of a man in a paternal role who sexually abuses a child there is often another non-abusing parent, i.e. the mother (Saradjian, 1997). Therefore, maternal sexual abuse is much more hidden and thus difficult to recognize and prevent. Supportive adults and systems have to be particularly sensitive from early on for the phenomenon of abusing mothers or co-abusive parents.

\section{Sexual Abuse in Early Childhood}

Sexual abuse in early childhood, i.e. below the age of three, is an underrepresented topic in research and practice (Children's Commissioner for England, 2015; Grebenstein, 2017; TrubeBecker, 2005). Considering international studies on prevalences of child sexual abuse (Clayton et al., 2018; Finkelhor, 2005; Stoltenborgh et al., 2011; Zimmermann, 2010) the complexity, global concerns and difficulties of international comparisons stand out; e.g., studies focus on a different age range (Zimmermann, 2010). Grebenstein (2017) illustrates in her analyses on child sexual abuse in infancy and early childhood, that although it is noted that sexual abuse occurs in all age groups, it is barely focused on children between 0-3 years of age.

Elisabeth Trube-Becker, the first female professor of forensic medicine in Germany, is one of the scientists who investigated sexual abuse in early childhood in Germany (Grebenstein, 2017). While focusing on forensic reports of (fatally) abused children and the examination of injuries (on genitals and erogenous zones), Trube-Becker finds evidence that infants and very young children can be victims of sexual abuse (Trube-Becker, 1982; Trube-Becker, 1986). The youngest victim of child sexual abuse in her sample was nine months old (Trube-Becker, 1982).

Children at that age are mainly cared for in the family environment. In Germany, the majority of children under three years are cared for at home, with $70 \%$ of the children in former West Germany and 48\% in former East Germany in 2019 (Autorengruppe Bildungsberichterstattung, 2020). It decreases with age, thus almost all children between three and six years (93\% in 2019) are in institutionalized care (Autorengruppe Bildungsberichterstattung, 2020). Although children under the age of one year are even more often cared for exclusively within the family (98\% in former West Germany and $97 \%$ in former East Germany) (Autorengruppe Bildungsberichterstattung, 2020).

Considering abusive family environments, a special focus should be put on the first years of life and specific aspects need to be considered. Children under the age of three, are not able to speak fluently. Thus, it is a sensible age, in which the children are 
totally dependent on their environment and cannot disclose easily when abused. For instance, looking at a critical assessment on sexual abuse within the family environment in England (Children's Commissioner for England, 2015), the analysis concludes that especially children under the age of five are underrepresented, as "[they] may not be able to recognise that they have been sexually abused, and perpetrators may normalise their behaviour." (Children's Commissioner for England, 2015, p. 9). Interestingly, the report elaborates "(...) some specialist services report that they work mostly with victims of child sexual abuse in the family environment under the age 5." (Children's Commissioner for England, 2015, p. 45). In addition, Grebenstein portrays that the underrepresentation of research in Germany could also be due to the general assumption that it is not or if so a marginalized topic (Grebenstein, 2017). Besides, the underrepresentation might also be due to the fact that it is hard to investigate, as verbally questioning infants and toddlers is not possible and directly questioning the suspected mothers might lead to wrong answers. Even when children are able to speak at the age of around two to three years, they might not be able to frame the violation of their rights as their skills are only emerging and there might be no words to describe what happened (Finkelhor, 2008; Todt et al., 2014). Especially in the first years of life, children might be missing important and trustful adults outside their family, who they have regular contact to, e.g. kindergarten or nursery teachers, and could somehow disclose to (Gerke et al., 2019b). To clearly reveal sexual abuse, children need knowledge and words to express themselves as well as trustful adults as contact persons who know how to react.

In Germany, kindergarten usually starts at the age of three years. In 2013, a law ( $\$$ 24 SGB VIII) was passed to guarantee one - and two-year-old children a place in a daycare (Kindertagespflege, Kindertageseinrichtung) (Anton et al., 2021). Parents increasingly express the need for institutionalized care for children under the age of three and throughout Germany, thus there is a greater demand than available places in daycare, as well as a strong variation depending on the region (Alt et al., 2020; Anton et al., 2021). The demand for childcare under the age of three increased from 39\% to $49 \%$ between 2012 and 2019 (Anton et al., 2021). Regardless of the general trend toward more frequent and earlier extra-family care, the changing conditions of growing up, a raise of working mothers and a growing attention on early institutional care, children under the age of three years in particular continue to be cared for mainly or even exclusively within the family (Autorengruppe Bildungsberichterstattung, 2020).

If in early childhood, the mother is a perpetrator of sexual abuse, children need professionals and other extra-family members in their social surrounding, who are aware of the "friendly mother illusion". In early childhood, this means to have adults who take care of the child's well-being and act for them in case of danger. Children need reference persons, who are aware of the phenomenon of sexual abuse and especially maternal sexual abuse. In this regard, professionals, especially those working with young families, require knowledge about abusing mothers and associated risk factors.

\section{Future Directions in Prevention of Maternal Sexual Abuse in Early Childhood}

Children in their early years are especially vulnerable, as they are dependent on a caring social surrounding. Following David Finkelhor (2008), the vulnerability of children is due to lack of: Physical strength and size; knowledge, experience, and self-control; 
the choice over associates; awareness in society about what children hurts alongside with sanctions against violence against children. Considering sexual abuse in early childhood with the mother as a perpetrator, the awareness of the social surrounding of the child is the most important point, as children up to the age of three are physically weak, cannot verbally disclose and cannot choose who they are with. In early childhood, the family is the main social context for a child and parents or caregivers are mainly responsible for a supportive and safe upbringing. In cases, in which the family is not a safe place, professionals, like e.g. pediatricians, midwives, nursery and kindergarten teachers and adults in the social environment of the child are the primary protective factor for children from early on - provided that they are aware of the phenomenon and sensitive to indications.

Vignette studies found that professionals confirmed the importance of treating femaleperpetrated child sexual abuse the same way they would treat child sexual abuse perpetrated by males (Christensen, 2018; Hovey et al., 2013); however, the problem was recognizing it. Moreover, professionals perceived sexual abuse by males and females differently regarding the severity, the negative impact on the victim as well as the need to act (Hetherton \& Beardsall, 1998; Kite \& Tyson, 2004; Mellor \& Deering, 2010). This indicates that when professionals are questioned about female-perpetrated child sexual abuse they do acknowledge the importance of being aware of it, but they are often not able to recognize a case of female perpetration. There is a need for specific knowledge on the phenomenon of maternal abuse in early childhood to inform professionals and society about the prevalences, types, disclosure mechanisms, long-lasting consequences and thus the need to act. Specifically, the risk factors of young mothers are important to know, e.g., the possibility of transgenerational transmission of abuse, as a high proportion of female abusers have experienced child sexual abuse themselves (Colson et al., 2013).

In Germany, the law on cooperation and information in child protection (KKG) enacted in 2012 describes the right for parents to be supported in raising their children by services of the state. It specifies the right for a coordinated, early, and multi-professional support offer for families including information, counseling and help with regard to the development of children, especially in the first years of life ( 11 Abs. 4 KKG). Furthermore, it is the fundament of the so-called Early Childhood Interventions ("Frühe Hilfen") in Germany, which are guided by the National Center of Early Prevention (Nationales Zentrum Frühe Hilfen [NZFH]). The offers are free of charge, for all families (to be) and aim to enable a low-threshold accessibility for families in particular psychosocial stress situations (National Centre for Early Prevention, 2018). Furthermore, they focus on creating multi-professional networks, to keep children safe, while especially enhancing the cooperation and the exchange between the health and social sector (Atabaki et al., 2013; Benz \& Sidor, 2013; National Centre for Early Prevention [NZFH], 2018; Renner et al., 2018). Also early prevention initiatives must consider society's "friendly mother illusion" and need to be sensitive to the possibility of mothers as perpetrators. Especially young children need advocates outside the family. In Germany therefore, all parents are obliged to several medical check-ups from the time of birth throughout childhood (U-Untersuchungen) (Jud, 2015).

Overall, we suggest the following future directions in research and prevention of maternal sexual abuse in early childhood:

(1) Trainings for professionals, who are in contact with mothers and small children are needed regarding the topics maternal abuse as well as sexual abuse in early childhood. 
Existing trainings and workshops on child sexual abuse must cover maternal sexual abuse in early childhood and sensitize participants for these types of child abuse that occur less frequent. Following Kydd (2003), we argue that prevention strategies need to be diverse and include different actors and systems that are involved in children's lives, e.g. health, social and juridical services. Especially professionals in contact with mothers and children from early on, like midwives, pediatricians, gynecologists, social workers, etc. should be included. Approaches and trainings in child protection, which raise awareness and communicate knowledge on procedural steps for individual professions and possible challenges in the event of suspicion, are needed.

(2) Specific low-threshold and anonymous services, such as online platforms or telephonic help lines, for mothers with newborn babies, especially mothers with risk factors such as own history of maltreatment or psychiatric disorder (Colson et al., 2013) are suggested. Furthermore, primary prevention, such as services for parents with young children in general including information on the burden that can occur and where to find help could be important. While facing the so called 'prevention dilemma' ("Präventionsdilemma") (Bauer \& Bittlingmeyer, 2005; van Staa \& Renner, 2020) in Germany, which states that especially families in need of support are hard to reach or do not use support offers, it is vital to know what mothers themselves consider as helpful and important to trust professionals and accept help.

(3) More empirical research on the causes, risk and protective factors and prevalences of maternal sexual abuse is needed to create a basis for specific prevention programs. Furthermore, research has not yet recognized sufficiently the specific risk of very young children who are often exclusively cared for by their mother, thus research must distinguish between children of very young age to adolescents. Another research question should treat situations, which could be challenging for mothers and what or who they would need in such situations to stay calm and confident. Moreover knowledge in child protection is needed, which focusses on very young children, i.e. 0-3 years of age, their exposure on sexual violence and its prevention and intervention. Reducing the range of age groups within studies on sexual abuse could be a first step to gather more knowledge.

\section{Conclusion}

Following Admon Livny and Katz (2018) raising awareness is a form of prevention. Especially in the first years of their lives, children are dependent on caring adults, often their mothers, and need active systems focusing on early prevention. This essay sheds light on the topic of sexually abusing mothers as well as early sexual abuse and its prevention. Maternal abuse often occurs in a hidden way and cannot be easily disclosed by the victims when they are young, especially in infancy as they can neither speak, nor choose who they are with. In cases of sexual abuse in early childhood, specifically maternal sexual abuse, infants and young children as the most vulnerable members of the family need an advocate. Specific attention must be drawn on the need of available adults for children, who recognize and consider that mothers can be perpetrators of child sexual abuse and that sexual abuse occurs in early childhood. Considering that research and society is already starting to discuss the high evidence of abuse within the family and in institutions, we took the next 
step and pointed out the topic of mothers as perpetrators of sexual abuse in the early years of a child.

Within the field of maternal abuse, as well as sexual abuse in early childhood there is still a lack of knowledge. Further research should address the different types of female abusers, evaluate on mothers as perpetrators with a focus on specific risk factors and interventions in early childhood and thus the far underestimated topic of maternal sexual abuse in early childhood. We argue that so far marginalizes types of sexual abuse need to be considered specifically, early, and interdisciplinary. There is a need for a network of professionals, who are aware of abusing mothers from early on and discuss the topic to prevent and intervene.

Authors' Contributions Both authors contributed equally to literature research as well as manuscript drafting.

Funding Open Access funding enabled and organized by Projekt DEAL.

\section{Declarations}

Conflicts of Interest We have no conflicts of interest to declare.

Open Access This article is licensed under a Creative Commons Attribution 4.0 International License, which permits use, sharing, adaptation, distribution and reproduction in any medium or format, as long as you give appropriate credit to the original author(s) and the source, provide a link to the Creative Commons licence, and indicate if changes were made. The images or other third party material in this article are included in the article's Creative Commons licence, unless indicated otherwise in a credit line to the material. If material is not included in the article's Creative Commons licence and your intended use is not permitted by statutory regulation or exceeds the permitted use, you will need to obtain permission directly from the copyright holder. To view a copy of this licence, visit http://creativecommons.org/licenses/by/4.0/.

\section{References}

Admon Livny, K., \& Katz, C. (2018). Schools, Families, and the Prevention of Child Maltreatment: Lessons That Can Be Learned From a Literature Review. Trauma, Violence \& Abuse, 19(2), 148-158. https:// doi.org/10.1177/1524838016650186

Alt, C., Anton, J., Gedon, B., Hubert, S., Hüsken, L., Lippert, K., \& Schickle, V. (2020). DJI-Kinderbetreuungsreport 2019: Inanspruchnahme und Bedarf aus Eltern- perspektive im Bundesländervergleich. München.

Anton, J., Hubert, S., \& Kuger, S. (2021). Der Betreuungsbedarf bei U3- und U6-Kindern: DJI Kinderbetreuungsreport 2020 (No. 1). München.

Atabaki, A., Heddaeus, D., Metzner, F., Schulz, H., Siefert, S., \& Pawils, S. (2013). Implementing an Inpatient Social Early Warning System for Child Maltreatment. Research on Social Work Practice, 23(2), 189-198. https://doi.org/10.1177/1049731512469279

Autorengruppe Bildungsberichterstattung. (2020). Bildung in Deutschland 2020: Ein indikatorengestützter Bericht mit einer Analyse zu Bildung in einer digitalisierten Welt. Bildung in Deutschland: 2020. Bielefeld: wbv.

Banning, A. (1989). Mother-son incest: Confronting a prejudice. Child Abuse \& Neglect, 13(4), 563-570.

Barth, J., Bermetz, L., Heim, E., Trelle, S., \& Tonia, T. (2013). The current prevalence of child sexual abuse worldwide: A systematic review and meta-analysis. International Journal of Public Health, 58(3), $469-483$.

Bauer, U., \& Bittlingmayer, U. H. (2005). Wer profitiert von Elternbildung? Zeitschrift Für Soziologie Der Erziehung Und Sozialisation, 25(3), 263-280.

Benz, M., \& Sidor, A. (2013). Early intervention in Germany and in the USA: A comparison of supporting health services. An overview article. Mental Health \& Prevention, 1(1), 44-50. https://doi.org/10. 1016/j.mhp.2013.10.004 
Bieneck, S., Stadler, L., \& Pfeiffer, C. (2011). Erster Forschungsbericht zur Repräsentativerhebung sexueller Missbrauch 2011. Hannover: Kriminologisches Forschungsinstitut Niedersachsen (KFN).

Brüning, T., Mohr, C., Clauß, D., Ramsauer, T., \& Simon-Stolz, L. (2019). Auswirkungen und Folgen von Kindesmisshandlung und Vernachlässigung. Monatsschrift Kinderheilkunde, 167(10), 881-890. https://doi.org/10.1007/s00112-019-0762-9

Children's Commissioner for England (2015). Protecting children from harm: A critical assessment of child sexual abuse in the family network in England and priorities for action. London.

Clayton, E., Jones, C., Brown, J., \& Taylor, J. (2018). The Aetiology of Child Sexual Abuse: A Critical Review of the Empirical Evidence. Child Abuse Review, 27(3), 181-197. https://doi.org/10.1002/car. 2517

Christensen, L. S. (2018). Professionals' perceptions of female child sexual offenders. Journal of Interpersonal Violence. https://doi.org/10.1177/0886260518785377

Clemens, V., Huber-Lang, M., Plener, P. L., Brahler, E., Brown, R. C., \& Fegert, J. M. (2018). Association of child maltreatment subtypes and long-term physical health in a German representative sample. European Journal of Psychotraumatology, 9(1), 1510278. https://doi.org/10.1080/20008198.2018. 1510278

Colson, M. H., Boyer, L., Baumstarck, K., \& Loundou, A. D. (2013). Female sex offenders: A challenge to certain paradigmes. Meta-Analysis. Sexologies, 22(4), e109-e117.

Deering, R., \& Mellor, D. (2010). What is the prevalence of female-perpetrated child sexual abuse? A review of the literature. American Journal of Forensic Psychology, 28(3), 25-53.

Deering, R., \& Mellor, D. (2011). An exploratory qualitative study of the self-reported impact of femaleperpetrated childhood sexual abuse. Journal of Child Sexual Abuse, 20, 58-76.

Denov, M. S. (2003). To a safer place? Victims of sexual abuse by females and their disclosures to professionals. Child Abuse \& Neglect, 27(1), 47-61.

Dube, S. R., Anda, R. F., Whitfield, C. L., Brown, D. W., Felitti, V. J., Dong, M., \& Giles, W. H. (2005). Long-term consequences of childhood sexual abuse by gender of victim. American Journal of Preventive Medicine, 28(5), 430-438.

Egle, U. T., \& Hardt, J. (2012). Gesundheitliche Folgen von Missbrauch, Misshandlung und Vernachlässigung in der Kindheit. In M. Cierpka (Ed.), Frühe Kindheit 0-3 Jahre: Beratung und Psychotherapie für Eltern mit Säuglingen und Kleinkindern (pp. 103-114). Berlin, Heidelberg: Springer Berlin Heidelberg.

Fegert, J. M., Rassenhofer, M., Schneider, T., Seitz, A., \& Spröber, N. (2013). Sexueller KindesmissbrauchZeugnisse, Botschaften, Konsequenzen. Beltz Juventa.

Felitti, V. J., Anda, R. F., Nordenberg, D., Williamson, D. F., Spitz, A. M., Edwards, V., \& Marks, J. S. (1998). Relationship of Childhood Abuse and Household Dysfunction to Many of the Leading Causes of Death in Adults. American Journal of Preventive Medicine, 14(4), 245-258. https://doi.org/10.1016/ S0749-3797(98)00017-8

Finkelhor, D. (2005). Zur internationalen Epidemiologie von sexuellem Missbrauch an Kindern. In G. Amann \& R. Wipplinger (Eds.), Sexueller Missbrauch: Überblick zu Forschung, Beratung und Therapie. Ein Handbuch (3rd ed., pp. 81-94). Tübingen: dgvt-Verlag.

Finkelhor, D. (2008). Childhood victimization: violence, crime, and abuse in the lives of young people. Oxford University Press.

Finkelhor, D., \& Russell, D. (1984). Women as perpetrators: Review of the evidence. Child Sexual Abuse: New Theory and Research, 171-187.

Finkelhor, D., Vanderminden, J., Turner, H., Hamby, S., \& Shattuck, A. (2014). Child maltreatment rates assessed in a national household survey of caregivers and youth. Child Abuse \& Neglect, 38(9), 1421-1435.

Geddes, R. A., Tyson, G. A., \& McGreal, S. (2013). Gender bias in the education system: Perceptions of teacher-student sexual relationships. Psychiatry, Psychology and Law, 20(4), 608-618.

Gerke, J., Jud, A., Rassenhofer, M., \& Fegert, J. M. (in review). Professionals' reactions to female-perpetrated child sexual abuse: A systematic literature review.

Gerke, J., Rassenhofer, M., Witt, A., Sachser, C., Fegert, J. M. (2019a) Female-perpetrated child sexual abuse: Prevalence rates in Germany. Journal of Child Sexual Abuse, 1-15. https://doi.org/10.1080/ 10538712.2019.1685616

Gerke, J., Fegert, J. M., \& Rassenhofer, M. (2019b). "The attention of my teacher helped me to survive"School as a place of resilience. Lernen Und Lernstörungen, 8(2), 112-120.

Grayston, A. D., \& De Luca, R. V. (1999). Female perpetrators of child sexual abuse: A review of the clinical and empirical literature. Aggression and Violent Behavior, 4(1), 93-106.

Grebenstein, A.-K. (2017). Sexualisierte Gewalt an Säuglingen Und Kleinkindern Im Kontext Früher Hilfen. https://doi.org/10.25595/1213 
Harris, D. A., \& Mayba, Y. (2017). An exploratory study of spontaneous recollections of female-perpetrated childhood abuse by men convicted of sexual offenses. Journal of Child and Adolescent Trauma, 10(2), 109-120.

Hetherton, J., \& Beardsall, L. (1998). Decisions and attitudes concerning child sexual abuse: Does the gender of the perpetrator make a difference to child protection professionals? Child Abuse \& Neglect, 22(12), 1265-1283.

Hillberg, T., Hamilton-Giachritsis, C., \& Dixon, L. (2011). Review of meta-analyses on the association between child sexual abuse and adult mental health difficulties: A systematic approach. Trauma, Violence \& Abuse, 12(1), 38-49. https://doi.org/10.1177/1524838010386812

Hovey, A., Rye, B. J., \& Stalker, C. A. (2013). Do therapists' beliefs about sexual offending affect counseling practices with women? Journal of Child Sexual Abuse, 22(5), 572-592.

Hunger, U. (2019). Verurteilte Sexualstraftäterinnen: eine empirische Analyse sexueller Missbrauchsund Gewaltdelikte. Duncker \& Humblot.

Jimenez-Borja, M., Jimenez-Borja, V., Borja-Alvarez, T., Jimenez-Mosquera, C. A. J., Murgueitio, J. (2020). Prevalence of child maltreatment in Ecuador using the ICAST-R. Child Abuse \& Neglect, 99.

Johansson-Love, J., \& Fremouw, W. (2006). A critique of the female sexual perpetrator research. Aggression and Violent Behavior, 11, 12-26.

Jud, A. (2015). Sexueller Kindesmissbrauch - Begriffe, Definitionen und Häufigkeiten. In J. M. Fegert, U. Hoffmann, E. König, J. Niehues, \& H. Liebhardt (Eds.), Sexueller Missbrauch von Kindern und Jugendlichen: Ein Handbuch zur Prävention und Intervention für Fachkräfte im medizinischen, psychotherapeutischen und pädagogischen Bereich (pp. 41-50). Springer.

Kendall-Tackett, K. A., Simon, A. F. (1987). Perpetrators and their acts: Data from 365 adults molested as children. Child Abuse \& Neglect, 11(2), 237-245.

Kendall-Tackett, K. A., Meyer Williams Linda, \& Finkelhor, D. (2005). Die Folgen von sexuellem Missbrauch bei Kidnern: Review und Synthese neuerer empirischer Studien. In G. Amann \& R. Wipplinger (Eds.), Sexueller Missbrauch: Überblick zu Forschung, Beratung und Therapie. Ein Handbuch (3rd ed., pp. 179-212). Tübingen: dgvt-Verlag.

Kite, D., Tyson, G. A. (2004). The impact of perpetrator gender on male and female police officers' perceptions of child sexual abuse. Psychiatry, Psychology and Law, 11(2), 308-318.

Kocturk, N., \& Yuksel, F. (2019). Characteristics of victims and perpetrators of intrafamilial sexual abuse. Child Abuse \& Neglect, 96, 104122.

Kydd, J. W. (2003). Preventing Child Maltreatment: An Integrated, Multisectoral Approach. Health and Human Rights, 6(2), 34-63. https://doi.org/10.2307/4065429

Maynard, C., \& Wiederman, M. (1997). Undergraduate students' perceptions of child sexual abuse: Effects of age, sex, and gender-role attitudes. Child Abuse \& Neglect, 21(9), 833-844.

McLeod, D. A. (2015). Female offenders in child sexual abuse cases: A national picture. Journal of Child Sexual Abuse, 24(1), 97-114. https://doi.org/10.1080/10538712.2015.978925

Mellor, D., \& Deering, R. (2010). Professional response and attitudes toward female-perpetrated child sexual abuse: A study of psychologists, psychiatrists, probationary psychologists and child protection workers. Psychology, Crime \& Law, 16(5), 415-438.

National Centre for Early Prevention. (2018). Mission Statement Early Childhood Intervention: Contribution by the NZFH Advisory Committee. Cologne.

Oliver, B. E. (2007). Preventing female-perpetrated sexual abuse. Trauma, Violence \& Abuse, 8(1), 19-32.

Pereda, N., Guilera, G., Forns, M., \& Gómez-Benito, J. (2009). The prevalence of child sexual abuse in community and student samples: A meta-analysis. Clinical Psychological Review, 73(6), 598-602.

Peter, T. (2008). Speaking about the unspeakable: Exploring the impact of mother-daughter sexual abuse. Violence against Women, 14(9), 1033-1053.

Renner, I., Saint, V., Neumann, A., Ukhova, D., Horstmann, S., Boettinger, U., Dreibus, M., KerlWienecke, A., Wulff, P., Mechthild, P., \& Thaiss, H. (2018). Improving psychosocial services for vulnerable families with young children: Strengthening links between health and social services in Germany. BMJ (clinical Research Ed.), 363, 1-9. https://doi.org/10.1136/bmj.k4786

van Staa, J., \& Renner, I. (2020). »Man will das einfach selber schaffen« - Symbolische Barrieren der Inanspruchnahme Früher Hilfen. Ausgewählte Ergebnisse Aus Der Erreichbarkeitsstudie Des NZFH. https://doi.org/10.17623/NZFH:K-SBIFH-AEE

Rogers, P., \& Davies, M. (2007). Perceptions of victims and perpetrators in a depicted child sexual abuse case: Gender and age factors. Journal of Interpersonal Violence, 22(5), 566-584.

Sahl, D., \& Keene, J. R. (2010). The sexual double standard and gender differences in predictors of perceptions of adult-teen sexual relationships. Sex Roles, 62(3-4), 264-277.

Saradjian, J. (1997). Factors that specifically exacerbate the trauma of victims of childhood sexual abuse by maternal perpetrators. Journal of Sexual Aggression, 3(1), 3-14. 
Sethi, D., Bellis, M., Hughes, K., Gilbert, R., Mitis, F., \& Galea, G. (2013). In Sethi D. (Ed.), European report on preventing child maltreatment. Copenhagen, Denmark: World Health Organization, Regional Office for Europe.

Stoltenborgh, M., Van Ijzendoorn, M. H., Euser, E. M., \& Bakermans-Kranenburg, M. J. (2011). A global perspective on child sexual abuse: Meta-analysis of prevalence around the world. Child Maltreatment, 16(2), 79-101.

Todt, M., Maciuga, A., \& Debertin, A. S. (2014). „Projekt Kinderschutz“ in Niedersachsen: Bilanz der Modellphase. Rechtsmedizin, 2014, 1-6. https://doi.org/10.1007/s00194-014-0968-z

Trube-Becker, E. (1982). Gewalt gegen das Kind: Vernachlässigung, Mißhandlung, sexueller Mißbrauch und Tötung von Kindern. Kriminalstatistik - Wissenschaft \& Praxis: 14. Heidelberg: Kriminalstatistik Verlag.

Trube-Becker, E. (1986). Mißhandelte Kinder - Opfer unserer Zeit. In V. Faust (Ed.), Compendium psychiatricum. Angst - Furcht - Panik: 19 Abbildungen, 17 Tabellen (pp. 171-176). Stuttgart: Hippokrates-Verlag.

Trube-Becker, E. (2005). Historische Perspektiven sexueller Kontakte zwischen Erwachsenen und Kindern/ Jugendlichen und die soziale Akzeptanz dieses Phänomens von der Zeit der Römer und Griechen bis heute. In G. Amann \& R. Wipplinger (Eds.), Sexueller Missbrauch: Überblick zu Forschung, Beratung und Therapie. Ein Handbuch (3rd ed., pp. 45-60). Tübingen: dgvt-Verlag.

Wiederman, M. W. (2005). The gendered nature of sexual scripts. The Family Journal: Counseling and Therapy for Couples and Families, 13(4), 496-502.

Witt, A., Münzer, A., Ganser, H. G., Fegert, J. M., Goldbeck, L., \& Plener, P. L. (2016). Experience by children and adolescents of more than one type of maltreatment: Association of different classes of maltreatment profiles with clinical outcome variables. Child Abuse \& Neglect, 57, 1-11. https://doi. org/10.1016/j.chiabu.2016.05.001

Zimmermann, P. (2010). Sexualisierte Gewalt gegen Kinder in Familien: Expertise im Rahmen des Projekts "Sexuelle Gewalt gegen Mädchen und Jungen in Institutionen“. Deutsches Jugendinstitut e.V.

Publisher's Note Springer Nature remains neutral with regard to jurisdictional claims in published maps and institutional affiliations. 